\title{
Lulismo e futebol: os discursos de um torcedor presidente
}

\author{
Fernando Mascarenhas* \\ Silvio Ricardo da Silva** \\ Mariângela Ribeiro dos Santos ***
}

\begin{abstract}
Resumo: Este artigo problematiza as mediações do lulismo com o futebol, sustentando que a modalidade esteve fortemente associada ao simbolismo popular e poder carismático de Lula. Assim, buscamos analisar como o futebol esteve inserido nos discursos do presidente. A partir de revisão e levantamento documental, foram analisados 309 discursos. Como resultado, identificamos três matrizes discursivas: a metafórica, pela qual a linguagem do futebol é usada como recurso identificatório e de projeção; a corintiana, na qual prevalece o discurso torcedor e opinativo; a pragmática, que acompanha a agenda modernizante para a realização da Copa do Mundo FIFA 2014.

Palavras-chave: Futebol. Lulismo. Esporte. Política.
\end{abstract}

\section{INTRODUÇão}

Luiz Inácio Lula da Silva deixou a presidência da República gozando de enorme popularidade. Seu sucesso e aprovação se justificaram, de um lado, pela adoção de uma política que, sem confrontar a ordem e sem promover rupturas efetivas com a macroeconomia do governo de seu antecessor, radicalizou ainda mais a ortodoxia fiscal e monetária do neoliberalismo, e, por outro, implantou uma política de mitigação da pobreza com medidas de promoção do mercado interno e proteção à parcela menos favorecida da população. Como resultado, parece ter governado a favor de todos, assegurando os privilégios e os lucros dos mais

\footnotetext{
*Professor, Programa de Pós-Graduação em Educação Física, Universidade de Brasília, Brasilia, DF. E-mail: fernandom@unb.br

**Professor, Programa de Pós-Graduação em Estudos do Lazer, Universidade Federal de Minas Gerais, Belo Horizonte, MG. E-mail: prof.srs@gmail.com

***Professora, Universidade do Estado da Bahia, Campus de Guanambi, Guanambi, BA. E-mail: angelamari.rs@bol.com.br
} 
poderosos e trazendo dezenas de milhões de brasileiros para a esfera do consumo.

Assim, Lula substituiu o debate programático e deu origem ao lulismo, segundo Singer (2009), um projeto sem rupturas e pluriclassista, combinando empenho redistributivo e simbolismo popular, apoiado na forte ligação dos pobres. Todavia, como lembra Ab'Sáber (2011), embora real e consistente, tal projeto foi também resultado de marketing e propaganda. Ao estilo "Lulinha paz e amor" , Lula disputou peladas em fins de semana e falou de política com termos do futebol, convertendo sua identificação com o esporte em capital político e reforçando seu estilo carismático de relação direta com os eleitores.

No Brasil, parece ser correto afirmar que falar sobre o futebol é uma forma de falar sobre o país ${ }^{2}$. Lula, que tantas vezes foi criticado por sua baixa escolaridade e por não dominar nenhuma língua estrangeira, foi eloquente na linguagem do futebol, o chamado "futebolês". Neste sentido, cabe problematizar: Como o futebol se relaciona com o lulismo? Como o tema do futebol esteve inserido nos discursos de Lula? O objetivo deste estudo consiste, portanto, em identificar e caracterizar as matrizes discursivas de Lula sobre o futebol.

\section{Delineamento do estudo}

Este estudo se apoiou em levantamento documental construído a partir de repositório institucional e fontes primárias, a saber: discursos do presidente Luiz Inácio Lula da Silva transcritos

\footnotetext{
${ }^{1}$ A construção da imagem "Lulinha paz e amor", dotando-o da possibilidade simbólica de liderar, por via negociação, as mudanças que o país necessitava, foi produzida pelo marqueteiro Duda Mendonça nas eleições presidenciais de 2002. Para tal, destacaram-se os seguintes expedientes: a moderação do discurso, a aceitação de compromissos assumidos pelo governo $\mathrm{FHC}$, o abandono dos ataques aos candidatos adversários e o uso intensivo de jingles e músicas como estratégia de propaganda eleitoral (RUBIM, 2003).

${ }^{2}$ Uma síntese sobre a trajetória dos estudos acadêmicos sobre o futebol brasileiro-em especial, aqueles que abordam sua relação com questões identitárias e com o campo da comunicação - pode ser localizada em Helal (2011). Neste percurso, a obra "Universo do futebol: esporte e sociedade brasileira", organizada por Damatta (1982), inaugura uma perspectiva em que o fenômeno do futebol é entendido como drama da vida social, um modo privilegiado de situar e expressar problemas significativos da sociedade brasileira, isto é, uma forma de falar sobre o país.
}

Movimento, Porto Alegre, v. 20, n. 2, p. 495-517, abr.jun. de 2014. 
e disponíveis no portal eletrônico da Biblioteca da Presidência da República ${ }^{3}$. O levantamento foi realizado no período de $1^{\circ}$ de janeiro 2003 a 31 de dezembro de 2010, correspondente aos seus dois mandatos. Conforme busca utilizando simultaneamente os descritores "discurso", "Lula" e "futebol", foram selecionados 420 discursos, o que corresponde a 16,27\% do total dos 2582 discursos disponíveis na base.

Quanto ao tratamento deste material, com a pretensão de se alcançar seus sentidos e significados, foi utilizado o método de análise de conteúdo (BARDIN, 2010). Assim, a atividade de préanálise, realizada a partir da leitura flutuante dos 420 discursos inicialmente selecionados, permitiu a definição de um corpus de análise constituído por 309 discursos $^{4}$. Considerando a frequência dos temas observados, o conjunto destes discursos foi agrupado em três unidades temáticas, conforme Quadro 1.

Quadro 1: Distribuição dos discursos agrupadas por Unidade Temática

\begin{tabular}{|l|c|}
\hline Unidades & Discursos \\
\hline Discursos contendo metáforas do futebol & 101 \\
\hline Discursos contendo alusão ou exaltação do Corinthians & 70 \\
\hline Discursos sobre ações de governo no setor esportivo & 70 \\
\hline Outros discursos com referências pontuais ao futebol & 68 \\
\hline Total & $\mathbf{3 0 9}$ \\
\hline
\end{tabular}

Fonte: Elaboração própria (2011)

A análise propriamente dita, o que envolveu a leitura de todo o conteúdo, foi balizada por um quadro teórico construído por meio de revisão de literatura relativa à biografia de Lula, ao

\footnotetext{
${ }^{3}$ Todos os discursos presidenciais em eventos ou solenidades oficiais são disponibilizados na íntegra e podem ser encontrados no portal eletrônico da Secretaria de Imprensa da Presidência da República. Ver: http://www2.planalto.gov.br/imprensa/discursos. Com o término do mandato, os discursos de ex-presidentes são transferidos para a Biblioteca da Presidência da República. Disponível em: http://www.biblioteca.presidencia.gov.br. Acessado entre 7 e 25/3/2011.

${ }^{4}$ Após a leitura flutuante dos 420 discursos inicialmente selecionados, 111 registros foram desprezados, 49 por serem discursos duplicados, 7 por serem discursos do vice-presidente José de Alencar e 55 por não se tratarem propriamente de discursos - 30 entrevistas e 25 registros de anais de eventos.
}

Movimento, Porto Alegre, v. 20, n. 2, p. 495-517, abr.jun. de 2014. 
governo Lula, ao lulismo e ao futebol. Partindo dessa organização, passamos a apresentação dos resultados da pesquisa, cujos recortes de análise foram organizados a partir da tematização que orientou o agrupamento dos discursos, antecedida de breve discussão sobre o lulismo.

\section{BASES DO LULISMO}

Por detrás da aparente semelhança dos resultados eleitorais de 2002 e 2006, dos pouco mais de 20 pontos percentuais que distanciaram Lula de Serra e de Alckmin ${ }^{5}$, está encoberta uma movimentação importante do eleitorado, com a troca dos estratos sociais que deram a vitória a Lula e ao PT em cada um dos pleitos. Para Singer (2009), é a partir deste realinhamento que emerge o fenômeno do lulismo. Se antes o PT foi apoiado por uma classe média progressista, por eleitores de alta escolaridade, com maior presença no eixo sul-sudeste e nos grandes centros urbanos, a partir de 2002 modifica-se a tônica de seu eleitorado, até então com características pronunciadamente ideológicas.

Embora a formação inicial do PT esteja associada a interesses organizados em torno da contradição entre capital e trabalho, o que demonstram os números da eleição de Lula em $2006^{6}$, cuja tendência se repete na eleição de Dilma Rousseff em 2010, é que a polarização eleitoral se deu para além das classes fundamentais, burguesia versus proletariado. Isto porque o PT passou a representar na arena política mais o subproletariado e menos o proletariado ${ }^{7}$. Apoiado pela população de baixa e baixíssima renda, ganhou a

\footnotetext{
${ }^{5}$ Conforme dados do TSE, Lula foi eleito em 2002 com $61,27 \%$ dos votos contra $38,72 \%$ obtidos por seu oponente, José Serra, e reeleito em 2006 com 60,83\% contra 39,17\% de Geraldo Alckmin, ambos do PSDB. Disponível em: http://www.tse.jus.br/eleicoes/eleicoesanteriores. Acessado em 5/5/2011.

${ }^{6}$ Os votos que elegeram Lula no pleito de 2002 ainda foram difusos, sem vínculo com algum estrato social em especial, mas indicando um processo de mudança. Mas na eleição de 2006, Lula e o PT adquirem ressonância popular, recebendo uma enxurrada de votos dos eleitores de baixa e baixíssima renda, de baixa escolaridade, do norte e nordeste e na periferia das metrópoles.

7 Subproletários, no vocabulário marxista, são aqueles situados socialmente abaixo do proletariado no que se refere às condições de vida e de trabalho. São os mais pobres entre os pobres, a fração da classe representada pelos eleitores de baixíssima renda.
}

Movimento, Porto Alegre, v. 20, n. 2, p. 495-517, abr./jun. de 2014. 
feição de um "partido dos pobres" e, mesmo sensibilizando um segmento ativo e organizado da sociedade civil, o lulismo provocou uma repolarização da disputa partidária no Brasil, a partir do conflito entre ricos e pobres (SINGER, 2012).

Ocorre que os subproletários constituem uma fração de classe com dificuldades para se organizar. Atomizados no sistema produtivo e destituídos da possibilidade de construir desde baixo a sua auto-organização autônoma, apresentam-se na arena política como massa e, como tal, tendem a se identificar com uma liderança que, desde o alto, coloque o Estado a seu favor. Este comportamento político sobre o qual se assenta o lulismo possui semelhança com o que Marx ([1852]) chamou de bonapartismo, modelo segundo o qual um governo centrado na figura de um líder consegue reunir poder suficiente para arbitrar os conflitos entre classes divergentes. Nesse sentido, a dimensão bonapartista do lulismo pode ser caracterizada a partir de um governo que, apoiado pelos mais pobres, colocou-se acima da luta entre as classes tradicionais, mantendo em equilíbrio demandas de trabalhadores e empresários.

Por conseguinte, o lulismo não representou uma ideologia, mas a desideologização da política (OLIVEIRA, 2010). O subproletariado, reconhecendo no lulismo a plataforma de diminuição da pobreza sem confrontar a ordem, pelo voto, afiançou a Lula o poder de arbitragem entre as classes fundamentais ${ }^{8}$. Neste cenário, a opção de Lula pelos mais pobres não desencadeou reformas anticapitalistas. Ordem e mudança, este foi o tom de seu governo que, sustentado numa espécie de reformismo fraco, promoveu uma tímida redução da desigualdade. A base material para a aderência ao lulismo esteve justamente aí, num projeto reformista de combate à pobreza delineado a partir de políticas de transferência de renda, expansão do crédito, valorização do salário mínimo e aumento do emprego formal, com a integração dos mais pobres via consumo e crédito (SINGER, 2012).

${ }^{8} \mathrm{O}$ sucesso da solução arbitral - uma categoria gramsciniana - depende de que os polos que ela equilibra não tenha força para impor sua própria solução. Assim, interesses e propostas divergentes são resolvidos pela arbitragem de um Executivo que se apresenta acima das classes (SINGER, 2012).

Movimento, Porto Alegre, v. 20, n. 2, p. 495-517, abr.jun. de 2014. 
Mas para além do empenho redistributivo, há de se considerar que o lulismo teve também um forte suporte simbólico, potencializando os mecanismos de identificação dos pobres com a figura de Lula. Convém lembrar que Lula foi o primeiro presidente que viveu a experiência da miséria e da pobreza. Isto mexeu com a auto-imagem do eleitorado popular. Os pobres viram em Lula um presidente amoroso e carismático, alguém que projetava suas aspirações, elevando-o à condição de condottiere e de mito (OLIVEIRA, 2010). Neste sentido, sem desconsiderar a base material e econômica, o lulismo deve também ser entendido à luz do simbolismo popular e poder carismático de Lula.

Ab'Sáber (2011) recorre à intersecção entre política e cultura para sustentar que o próprio Lula é a encarnação do pacto social que sustentou seu governo. Ao propor um governo para todos, absorvendo as representações corporativas de trabalhadores e empresários, conseguiu unificar o país em torno do ideal do consumo e de mercado que possibilitasse o acesso as suas benesses. Quando a crise internacional se manifestou, colocando em risco o crescimento do PIB do país, chegou a ir à TV conclamando o povo brasileiro a continuar consumindo. Na toada do seu novo desenvolvimentismo", foi o "cara"10, transformou no discurso a miséria em pobreza, a pobreza em classe média e a riqueza, como efeito de retórica, fez deixar de existir.

Lula também continuou a sinalizar de maneira simbólica muito mais nítida abertamente aos pobres, com o seu antigo habitus de classe, em festas juninas, churrascos com futebol e isopores de cerveja na praia privativa da presidência, além do famoso "futebolês" como língua política e metáfora geral, e assim convencendo-os facilmente pela identificação carismática (AB'SÁBER, 2011, p. 26).

\footnotetext{
${ }^{9}$ Uma análise crítica do novo desenvolvimentismo como uma formulação político-ideológica de desenvolvimento econômico pode ser apreendida a partir de Gonçalves (2012).

${ }^{10} \mathrm{Em}$ reunião de líderes do G20 - grupo de países desenvolvidos e em desenvolvimento - realizada em abril de 2009, em Londres, na Inglaterra, o presidente dos Estados Unidos, Barack Obama, afirmou que Lula "é o cara", identificando-o como o "político mais popular do mundo". Para Ab'Sáber (2011), foi a retórica singular e o potencial simbólico pop de Lula que o fez virar "o cara" para Obama, naquele momento, um presidente em busca de referência diante da crise econômica e social dos EUA.
}

Movimento, Porto Alegre, v. 20, n. 2, p. 495-517, abr./jun. de 2014. 
Paraná (2008), ao analisar a história de vida do menino do sertão pernambucano que veio de "pau de arara" para São Paulo, que morou na periferia e que engraxou sapato, que adorava bola quando criança, que chegou a jogar no São Caetano Futebol Clube na adolescência e que adorava as aulas de Educação Física do SENAI, do metalúrgico que disputava pelada com os companheiros na hora do almoço e que perdeu o dedo num acidente na fábrica, do sindicalista do $\mathrm{ABC}$ que ia à Praia Grande, que ficou viúvo, casou-se novamente e que sempre torceu para o Corinthians, do líder político que se transformou no primeiro presidente operário do país, revela como ele, Lula, um representante da cultura da pobreza $^{11}$, passou a integrar um outro grupo social, mas sem esquecer sua origem e antigo habitus de classe.

\section{A METÁFORA DA CONQUISTA}

A capacidade retórica de Lula, capaz de cativar interlocutores os mais distintos, mas alcançando com maior ressonância a população mais pobre, justifica-se, em grande medida, pelo uso da metáfora. Para Daltoé (2011), a língua de Lula representa um modo particular de enunciar a política, pois inclui o povo como um novo interlocutor na cena discursiva da política brasileira, estabelecendo maior interlocução à medida que, através da metáfora, partilha com ele os dizeres da cultura popular, sem que, necessariamente, partilhem o mesmo espaço físico. Não por acaso, o "futebolês", inteligível a quase todo brasileiro, sem excluir os mais ricos e sofisticados, foi uma língua usada para falar de perto ao povo mais pobre.

Quando vai chegando o final do governo, a gente vai tendo a sensação de que estava assistindo a uma partida de futebol, e eu vou falar em futebol, porque as pessoas mais humildes compreendem mais se eu filosofar futebol. Então, nessa partida

\footnotetext{
${ }^{11}$ A noção de cultura da pobreza serve para identificar um determinado padrão e estilo de vida e comportamento que se constitui e vigora através de gerações que pertencem a um mesmo grupo social e econômico, reunindo a adaptação e a reação dos pobres diante de sua posição marginal na sociedade capitalista (PARANÁ, 2008).
}

Movimento, Porto Alegre, v. 20, n. 2, p. 495-517, abr.jun. de 2014. 
de futebol, eu não tenho dúvida nenhuma de que nós estamos ganhando o jogo de quatro a zero, cinco a zero... E aí, nós temos três tipos de torcedor: nós temos aquele torcedor muito otimista, que acha que era impossível fazer mais, que nós fizemos de tudo, que os gols foram os mais bonitos que já foram vistos dentro do Maracanã. Nós temos aquele pessimista, aquele que fica: "Pô, só cinco a zero! Por que não fez 10? Porque não fez 15? Poderia ter feito mais!"’. Também não vai acontecer. $E$ aquele que é um pouco o que vocês são: o torcedor forte emocionalmente, mas também forte racionalmente, que vocês estão contentes com o 5 x 0 mas, ao mesmo tempo, acharam alguns gols bonitos, outros mais ou menos, outros feios, e acham que o time poderia ter feito mais, se não tivesse perdido tanta bola, se não tivesse dado passe errado. A política é um pouco assim. Eu sei que nós fizemos muito, mas eu sei também o quanto falta ser feito neste país ${ }^{12}$.

Para Sardinha (2008, p. 98), as metáforas podem ser entendidas como representações dos conceitos e, como tal, "residem na mente dos indivíduos e são compartilhadas por pessoas de uma mesma cultura. Os conceitos representados pelas metáforas são chamados de metafóricos porque unem dois domínios diversos". Na passagem citada, como domínio fonte, o futebol se une ao domínio alvo da política, emprestando a narrativa e as referências para a avaliação de seu governo. E se neste exemplo a metáfora do futebol aparece num discurso de final de mandato, é importante registrar que o mesmo recurso está presente na trajetória de Lula desde a primeira greve dos metalúrgicos em 1978.

Quando a direção do Sindicato dos Metalúrgicos realizou o primeiro piquete da história pós-1964, chamou o movimento de "corrente para frente". Vivia-se sob o impacto da vitória da copa de 1970, e o slogan "corrente para a frente", tão vinculado à ditadura militar, foi ironicamente o escolhido

\footnotetext{
${ }^{12}$ Discurso na cerimônia de entrega do Prêmio Nacional de Direitos Humanos e assinatura do encaminhamento ao Congresso Nacional da Convenção Internacional para a proteção dos direitos humanos dos trabalhadores migrantes. Brasília-DF, 13/11/2010.
}

Movimento, Porto Alegre, v. 20, n. 2, p. 495-517, abr./jun. de 2014. 
para enfrentá-la. Piquete? Não, piquetes são proibidos, fazemos apenas uma "corrente para a frente, para ver se o patrão melhora o nosso salário (PARANÁ, 2008, p. 434-435)

Desde então, o "futebolês" já se fazia presente na oratória de Lula, ora usado de forma autoconsciente, ora quase desapercebido na interação de seus discursos. Na retórica presidencial o futebol esteve associado, principalmente, ao conceito de governo.

Quero, mais uma vez, agradecer ao ministro Tarso Genro e à sua equipe, desejando ao nosso querido Fernando Haddad pleno sucesso e que continue fazendo as coisas boas que estão fazendo, porque nós aprendemos, na prática do futebol, que em time que se ganha a gente não mexe, deixa ele continuar ganhando ${ }^{13}$.

Aqui, a associação entre futebol e governo aparece igualando sua equipe de governo a um time de futebol. Esta, aliás, foi uma metáfora presente em todos os discursos de Lula que envolveram a posse de ministros, o que, para nós, pode ser comparado à preleção do técnico aos seus jogadores antes de entrarem em campo. Contudo, o domínio alvo de suas metáforas não se restringiu apenas ao conceito de governo. Lula se valeu deliberadamente das metáforas quando precisou falar de temas críticos e complexos, traduzindo-os para uma base cognitiva comum.

Seria quase desnecessário eu falar sobre a crise, depois de ouvir o Presidente do Banco Central, o Ministro da Fazenda, a Ministra-Chefe da Casa Civil e nove companheiros conselheiros falando. Primeiro, porque há uma concordância, eu diria, pelo que nós conhecemos da crise, no diagnóstico dessa crise. [...] A segunda coisa é que eu tenho uma... todo mundo sabe que eu gosto de futebol, sigo futebol, já joguei futebol - não fui bom, mas já joguei - e eu utilizo muito o futebol nas minhas falas porque é a coisa que pelo menos $90 \%$ dos brasileiros entendem ou pensam que entendem.

\footnotetext{
${ }^{13}$ Discurso na cerimônia de apresentação da proposta do Projeto de Lei de Educação Superior e posse do ministro de Estado da Educação, Fernando Haddad. Brasília-DF, 29/7/2005.
}

Movimento, Porto Alegre, v. 20, n. 2, p. 495-517, abr.jun. de 2014. 
Eu sempre trabalhei com a seguinte idéia: a melhor defesa é o ataque. E todo mundo sabe também que um time que está ganhando, se passar para a retranca, ele tem chance de permitir ao outro time que ganhe o jogo. A história do futebol é cheia de exemplos. Tem time que faz $1 \mathrm{x} 0$, recua todo mundo, o adversário bate, bate, bate, e "água mole em pedra dura tanto bate até que fura". No futebol é assim: um time medroso, tanto leva escanteio, tanto leva bola cruzada, que uma hora a bola entra. Agora nós tomamos a decisão de não permitir que a crise tenha no Brasil, primeiro, os efeitos que alguns querem que ela tenha, porque tem um problema na crise que é o pânico [...] Se a gente permitir que por medo as pessoas deixem de comprar [...] que por medo a pessoa deixa de financiar o seu sonho mágico de ter um carro. Se a gente permitir que o pânico tome conta da sociedade, o que vai acontecer? [...] Parece que tem gente que está torcendo para isso acontecer. E é exatamente contra esses que eu me insurjo todo santo dia vendendo otimismo ${ }^{14}$.

Desta vez, ligada à economia, a linguagem do futebol traduz uma mensagem de coalizão e otimismo diante do início da crise financeira internacional. Segundo Sardinha (2008), as metáforas de Lula ganhavam destaque pelo emprego da narrativa, destoando do restante de sua fala, e pela evocação de um assunto marcante na vida dos brasileiros. Assim, o poder dessa metáfora reside no fato de que, além de destoar do debate econômico, aliou o futebol - isto é, um assunto marcante - a provérbios comuns, um de domínio popular água mole em pedra dura tanto bate até que fura - e, outro, próprio do "futebolês" - $\mathrm{o}$ ataque é a melhor defesa. Nossa economia vai bem, mas como não podemos "dar moleza" para a crise, o consumo é a melhor defesa, em outros termos, foi o que disse.

Existem várias outras metáforas recorrentes no discurso de Lula, embora nem sempre apoiadas numa palavra e domínio de alto uso metafórico como o futebol. Sardinha (2008), com o uso de

\footnotetext{
${ }_{14}$ Discurso na reunião plenária do Conselho de Desenvolvimento Econômico e Social-CDES. Brasília-DF, 6/11/2008.
}

Movimento, Porto Alegre, v. 20, n. 2, p. 495-517, abr.jun. de 2014. 
ferramentas da linguística, mostrou que a conquista é uma metáforachave na retórica de Lula, gerando grande variedade de metáforas ao se combinar com outras metáforas e domínios. Retomemos o primeiro discurso citado, em que Lula se vale do domínio do futebol e da narrativa de uma partida ganha por 5 x 0 para estabelecer referências positivas para avaliação de seu governo. Neste mesmo discurso, tomado em seu todo, a palavra futebol aparece 4 vezes, enquanto a palavra conquista e suas derivações aparecem 14 vezes. Conquistamos cidadania, direitos, democracia, credibilidades, respeito, confiança, liberdade etc., ou seja, uma vitória de 14 x 0 , mas, para Lula, ainda dava para ter feito mais.

Em reforço ao clichê de que o Brasil é o país do futebol ${ }^{15}$, o presidente abusou da associação de que se somos bons no futebol, podemos ser bons também em outros domínios.

Nós imaginávamos formar dez mil doutores, já chegamos a 10 mil e 500 doutores e queremos criar uma marca, de que o Brasil nunca mais possa retroceder na formação de doutores, porque é isso que vai ser o charme do Brasil daqui para a frente, ou seja, não é criança de rua, não vai ser mais favela ou palafita, não vai ser mais apenas o carnaval ou o futebol ${ }^{16}$.

Apoiada em sua história de vida, uma pessoa que sofreu, mas que soube lutar e vencer as dificuldades até chegar ao cargo mais importante do país, a conquista, conforme analisa Sardinha (2008), constitui a própria metáfora da vida de Lula. Sua conduta política, segundo observa Paraná (2008), forja-se na ideia de emancipar os brasileiros da cultura da pobreza - o que corresponde à conquista encarnada em si mesmo e em sua família - e estabelecer uma ligação com o futuro para a mobilidade econômica das pessoas e da nação.

\footnotetext{
${ }^{15}$ Segundo Helal (2011, p. 29), "o país do futebol não é realidade natural, mas uma construção realizada por agentes - da imprensa, do meio acadêmico e da política - em determinado momento histórico [a partir dos anos 1930]. Dissemos que somos o "país do futebol" como forma de nos sentirmos distintos, únicos, singulares". Para saber mais sobre a "invenção" do país do futebol, ver Soares e Lovisolo (2001).

${ }^{16}$ Discurso na visita ao Complexo Industrial Ford Nordeste, Camaçari-BA, 5/4/2006.
}

Movimento, Porto Alegre, v. 20, n. 2, p. 495-517, abr.jun. de 2014. 


\section{Paixão pelo Corinthians}

Lula aprecia o futebol desde sua infância e, quando adulto, além de peladeiro de fins de semana, até se tornar presidente, foi também frequentador dos estádios. A sua paixão pelo futebol, aliada à retórica, manifesta-se pelo uso frequente da metáfora do futebol. É importante destacar, no entanto, que o futebol não figurou em seus discursos apenas como metáfora. Movido pela paixão, muitas vezes Lula deixou de lado o discurso pré-elaborado para dar sua opinião e testemunho de torcedor.

Eu queria terminar lendo apenas duas páginas aqui do que estava escrito, porque senão o pessoal que faz o discurso fica achando ruim. Eu acho que se nós tratarmos o futebol brasileiro como patrimônio nacional, eu vou dar um exemplo aqui para o presidente do Internacional, eu sou simpático, sou torcedor do Internacional, no Rio Grande do Sul, embora seja apaixonado pelo Grêmio, porque eu vi o Grêmio fazer um jogo com o Cruzeiro em que o Grêmio estava perdendo o jogo, eu estava com o Tarso Genro, o que eu vi aquela torcida fazer e o que eu vi aqueles jogadores fazerem dentro de campo! Somente a autoestima é que leva um time a fazer aquilo ${ }^{17}$.

O presidente fazia questão de manifestar suas preferências por um ou outro time. Poderia até se dizer que era um verdadeiro "viracasaca", assumindo-se torcedor de diferentes times, a depender de onde e para quem discursava. Mas a declaração de amor e juras de fidelidade ao seu time do coração foi uma marca em seus discursos. Ao referir-se ao futebol, Lula fazia questão de evidenciar o seu pertencimento clubístico ${ }^{18}$. A simpatia e os comentários sobre a história e os feitos de outros times, algo muito presente em suas falas, é algo que se explica a partir de seu envolvimento e experiência com o futebol, mas sua paixão pelo Corinthians é inquestionável.

\footnotetext{
${ }_{17}$ Discurso na cerimônia de sanção da Lei da Timemania. Brasília-DF, 14/9/2006.

${ }^{18} \mathrm{O}$ pertencimento clubístico é a base do torcer no futebol no Brasil e é constituído por laços afetivos emprestado dos familiares e estão tramados a elementos de ordem econômica, social, cultural e a valores e identidades locais, regionais e nacionais (DAMO, 2001; 2008).
}

Movimento, Porto Alegre, v. 20, n. 2, p. 495-517, abr./jun. de 2014. 
Eu nem bem sabia o que era futebol, porque tinha vindo de Pernambuco com 7 anos de idade, em 52; em 54 o Corinthians foi campeão e, por conta de tudo o que aconteceu, eu morava em Itapema, Vicente de Carvalho hoje, lá em Santos, e não virei santista nem virei Jabaquara, virei corintiano, em 54. Bom, de lá para cá, o Corinthians faz parte das minhas alegrias, dos meus sofrimentos. Você não sabe Marcelinho, o quanto você me fez sofrer quando você perdeu o pênalti contra o Palmeiras na decisão da Libertadores. Eu estou com 60 anos, foi a única vez que eu pensei que ia ter um enfarte, porque eu não acreditava que aquilo tinha acontecido, mas aconteceu ${ }^{19}$.

Segundo Lula, o Corinthians lhe proporcionou muitas alegrias e tristezas, sentimentos que, como torcedor, pôde experimentar várias vezes ao acompanhar seu time, independente de onde fosse jogar. Nesse sentido, a memória do Corinthians integra a narrativa que conta sua própria história de vida.

Em 1958, Zagallo, eu tinha 13 anos de idade. Eu me lembro da Seleção Brasileira jogando contra o Corinthians, e me lembro que pelo fato de o Gilmar estar na Seleção, o goleiro do Corinthians era o Cabeção. Eu me lembro da raiva com que eu saí do estádio do Pacaembu, em 1957, quando o De Sordi e a turma dele tiraram o título do Corinthians. Eu me lembro quando o Djalma Santos, quase um herói anônimo na Portuguesa de Desportos, antes de ir para o Palmeiras, fazia espetáculo jogando na lateral direita. Do Pelé eu não vou falar, porque a minha relação com o Pelé é uma relação de amor e ódio. É uma relação de admiração como a coisa mais importante que aconteceu no futebol do mundo, mas ao mesmo tempo foram 15 anos de sofrimento, no período da minha adolescência. Você não sabe o que você poderia ter causado, com a sua turma, com o Zito, com o Pepe, a um jovem esperançoso, de tanto derrotar o Corinthians ${ }^{20}$.

\footnotetext{
${ }^{19}$ Discurso na inauguração do Memorial do Corinthians. São Paulo-SP, 27/1/2006.

${ }^{20}$ Discurso na solenidade de entrega da medalha Heróis de 1958 a jogadores da Seleção Brasileira de 1958. Brasília-DF, 26/6/2008.
}

Movimento, Porto Alegre, v. 20, n. 2, p. 495-517, abr.jun. de 2014. 
O uso da metáfora também conectou o torcedor Lula ao domínio da política, associando as alegrias e tristezas proporcionadas pelo Corinthians à sua capacidade de superação diante das derrotas eleitorais que sofreu em 1989, 1994 e 1998.

Mas olha, eu vou the contar uma coisa: foi o momento, foi o momento... eu já vivi muitas alegrias, já vivi muitas alegrias, já vivi muita tristeza. Eu torço para um time no Brasil, chamado Corinthians, que ficou 23 anos sem ser campeão, eu sofri muito. Eu perdi, Zuma, três eleições, eu perdi três eleições. Cada uma que eu perdia, eu chegava em casa, minha mulher falava: "Ô Lula, você não acha que está na hora de parar, meu filho, não acha?". E eu notava que os meus amigos também gostariam que eu parasse, viu, Zuma? $\mathrm{Eu}$ ficava achando que os meus companheiros também queriam que eu parasse. Mas eu perdia as eleições no mês de outubro, ficava lambendo as feridas entre novembro e dezembro, e quando chegava janeiro, eu tinha que começar a viajar o Brasil outra vez para levantar a moral da tropa, porque se a gente não levantar a moral o pessoal desanima $^{21}$.

Enfim, pode-se dizer que a paixão pelo Corinthians fez do discurso de Lula sobre o futebol um discurso opinativo que poderia ser vocalizado por qualquer corintiano. Entretanto, mesmo sem vínculo com seu campo de atuação, seus discursos gozavam de enorme representatividade. Ocorre que, mesmo na condição de um agente da política, Lula estava autorizado a discursar sobre o futebol em função de sua autoridade institucional, era um torcedor investido de poder (CAVALCANTI; CAPRARO, 2012). Assim, pelo menos no que se refere ao futebol, assumia-se mais torcedor do que presidente ${ }^{22}$. Além de ter produzido identificação popular, este tipo de discurso, opinativo e apaixonado, teve também implicações

${ }^{21}$ Discurso no encerramento do Fórum Empresarial Brasil-África do Sul. Johannesburgo-África do Sul, 9/7/2010.

22 "Antes de ser presidente da República, eu sou brasileiro. Antes de ser presidente da República, eu sou fanático por esporte e, dentro do esporte, o futebol." Discurso na cerimônia de sanção da Lei da Timemania. Brasília-DF, 14/9/2006.

Movimento, Porto Alegre, v. 20, n. 2, p. 495-517, abr.jun. de 2014. 
na esfera da ação política, sobretudo, quando observamos os programas e ações de seu governo no setor esportivo.

\section{Pragmatismo político}

Foi com a determinação de um torcedor apaixonado que Lula pautou as ações de seu governo para o setor esportivo, com destaque para a transformação do Estado em principal parceiro das entidades de administração do futebol no país. Tal parceria ficou evidente, principalmente, a partir da retomada do diálogo com a CBF quando da organização do amistoso da Seleção Brasileira no Haiti, realizado em 2004, e da decisão de sediar a Copa do Mundo FIFA 2014²3, anunciada em 2007.

Eu queria dizer ao presidente da Fifa, presidente Blatter, da alegria de ver o nome do Brasil aparecer naquela papeleta. Quero agradecer a todo o Comitê Executivo da Fifa, aos presidentes de federações e agradecer ao Ricardo Teixeira pelo empenho, não agradecer, dar os parabéns pelo empenho. Eu quero tranqüilizar os dirigentes da Fifa. Essa não é uma responsabilidade do atual presidente, nós estamos aqui assumindo uma responsabilidade enquanto nação, enquanto Estado brasileiro para provar ao mundo que nós temos uma economia crescente ${ }^{24}$.

Em retrospectiva, cabe lembrar que logo no início de seu governo, Lula cria uma pasta exclusiva para tratar do esporte ${ }^{25} \mathrm{e}$, já em 2005, quando do lançamento da Política Nacional do Esporte, sinaliza sua vontade política de ver o Brasil como sede dos Jogos e da Copa.

\footnotetext{
${ }^{23}$ Para fins de simplificação, ao se referir a Copa do Mundo FIFA 2014, utilizaremos apenas a expressão Copa. O mesmo vale para os Jogos Olímpicos e Paraolímpicos de 2016, doraavante traduzidos pela expressão Jogos Olímpicos.

${ }^{24}$ Discurso na cerimônia de anúncio do Brasil como sede da Copa do Mundo de 2014. ZuriqueSuíça, 30/10/2007.

${ }^{25}$ Através da Medida Provisória no 103/2003, posteriormente convertida na Lei no 10.683/2003, o então Ministério do Esporte e Turismo foi separado em duas pastas, ficando o esporte com um ministério próprio.
}

Movimento, Porto Alegre, v. 20, n. 2, p. 495-517, abr.jun. de 2014. 
Se a gente quiser sonhar em um dia fazer uma Olimpíada aqui, no Brasil, ou a gente reconquistar o direito de fazer uma Copa do Mundo, nós temos que ser profissionais e fazer as coisas com muita competência, para que a gente possa mostrar ao mundo que nós não somos bons apenas no futebol, no vôlei, na natação, ou seja, nós somos bons na organização dos eventos internacionais com que nos comprometemos ${ }^{26}$.

Desde então, os megaeventos vão ampliando seu espaço na agenda de governo. Estava em jogo a funcionalização do esporte na direção do reposicionamento do país na geopolítica mundial e do desenvolvimento econômico nacional ${ }^{27}$. E se no plano mais geral o lulismo suprimiu o debate programático sobre o futuro da nação em nome de um projeto de desenvolvimento sem rupturas e pluriclassista, o que ocorreu no futebol não foi diferente, um pacto conservador para recuperação dos clubes, modernização dos estádios e atualização do ordenamento legal inerente ao setor, tudo em nome da preparação para a Copa.

Só para mostrar as minhas inquietações com o esporte, que é a maior paixão deste País. Eu acho que nós precisamos cuidar dele com muito carinho. É muito fácil o governo dizer que os problemas são dos clubes, é muito fácil dizer que o problema é tornar os clubes empresariais, é muito fácil dizer muita coisa. $\mathrm{O}$ dado concreto é que nós temos um problema na mão, que não é de nenhum individualmente, é de todos nós, e nós precisamos, juntos, assumir responsabilidades para salvar este patrimônio do Brasil chamado futebol ${ }^{28}$.

Se por um lado Lula falava da necessidade de um debate mais amplo sobre os problemas enfrentados pelos clubes no país, a

\footnotetext{
${ }^{26}$ Discurso na cerimônia de lançamento da Política Nacional de Esporte. São Paulo, 19/8/2005.

${ }^{27}$ Para saber mais sobre as relações de hegemonia e coalizão de interesses envolvendo a organização dos megaeventos esportivos no Brasil, ver Mascarenhas et al (2012).

${ }^{28}$ Discurso na cerimônia de entrega das garantias governamentais à CBF e assinatura da declaração de governo em apoio à realização da Copa do Mundo de Futebol em 2014 no Brasil. Brasília, 15/6/2007.
}

Movimento, Porto Alegre, v. 20, n. 2, p. 495-517, abr./jun. de 2014. 
exemplo da crise financeira e a ausência de gestão profissional, ao mesmo tempo, defendia a intervenção estatal no sentido de sanar suas dívidas. Com argumentos sustentados na paixão do povo brasileiro pelo futebol e no seu potencial para geração de emprego e renda, defendeu o apoio financeiro aos clubes.

Poucas coisas têm tanta importância para o nosso povo como o futebol. E todo mundo sabe que há muito tempo vários clubes profissionais do nosso país vivem uma profunda crise administrativa e financeira, com dívidas difíceis, eu diria, até impagáveis. Nós estamos aqui hoje para ajudar a resolver esse problema. Se não fosse pela importância da nossa paixão nacional, seria também porque o futebol é um setor de grande potencial empregador e de geração de recursos para o nosso povo e para o nosso país. $O$ futebol não sobrevive nem se desenvolve, em nenhum lugar do mundo, sem clubes fortes, saudáveis financeiramente e administrados com profissionalismo. Com a criação da Timemania, estamos fortalecendo o esporte, de modo geral, no nosso país. Estamos fazendo com que os clubes brasileiros de futebol, sem dúvida, a mais significativa referência esportiva do país, possam enfrentar seus problemas e continuar avançando na sua histórica trajetória de sucesso. É isso o que todos nós queremos ${ }^{29}$.

Para Lula, a retirada dos clubes de sua situação pré-falimentar era responsabilidade do Estado pelo fato do futebol compor o patrimônio cultural brasileiro. Mas isto não se faria apenas a partir de novas fontes de financiamento. Esperava-se modernizar a gestão do futebol brasileiro, o que significava profissionalizar a gestão dos clubes. Nesta linha, antes mesmo de lançar a Timemania ${ }^{30}$, o

\footnotetext{
${ }^{29}$ Discurso na cerimônia de lançamento nacional da Loteria Timemania. Brasília, 4/5/2005.

${ }^{30}$ Loteria instituída através da Lei no $11.345 / 2006 \mathrm{com}$ a finalidade de financiamento da dívida tributária dos clubes de futebol profissional. Posteriormente, revelou-se ineficiente, pois a dívida dos clubes cresceu em maior proporção que sua arrecadação. De todo modo, a Timemania pode ser considerada como uma das principais iniciativas do governo Lula afeta ao financiamento do futebol.
}

Movimento, Porto Alegre, v. 20, n. 2, p. 495-517, abr.jun. de 2014. 
presidente já havia sancionado a Lei de Modernização do Futebol ${ }^{31}$, adotando medidas com o objetivo de sua moralização, apontando para a transformação dos clubes em empresas, obrigando-os a prestarem contas de seus balanços financeiros e definindo a responsabilidade de seus dirigentes.

Muita gente acha que transformar o clube em empresa é pegar a Infraero para botar o seu nome na camisa de um clube. Isso não é transformar clube em empresa. Transformar clube em empresa é fazer com que nossos dirigentes sejam empresários de futebol, porque tem muitos empresários nossos que são empresários em sua atividade particular. Então, é um empresário bemsucedido fora do futebol, e no futebol ele é apenas dirigente do time, não é o empresário. E ele precisa tratar o clube como uma empresa. Aquele clube tem que gerar dinheiro, tem que gerar riqueza, tem que gerar um orçamento positivo, uma receita ${ }^{32}$.

Recuperar o futebol brasileiro, manter os craques da bola no país e preservar o futebol como patrimônio cultural e traço da identidade nacional são questões frequentes nos discursos do presidente Lula, mas ressaltando a necessidade e a importância de adequar o nosso futebol às exigências do esporte globalizado. Nesta perspectiva, houve também a preocupação com a segurança nos estádios. Junto com a Lei de Modernização do Futebol, Lula sancionou também o Estatuto de Defesa do Torcedor ${ }^{33}$, estabelecendo uma série de normas para a organização de espetáculos esportivos, envolvendo desde a venda de ingressos numerados, a inspeção da qualidade dos alimentos vendidos, a atribuição de responsabilidades ao organizador do espetáculo, a definição de planos de segurança, até

31 A Medida Provisória no 079/2003, posteriormente convertida na Lei no 10.672/2003, conhecida como Lei de Modernização do Futebol, através de alterações na Lei Pelé (no 9.615/1998), instituiu novos princípios para gestão do esporte como atividade econômica, a saber: transparência financeira e administrativa, moralidade na gestão desportiva, responsabilidade social de seus dirigentes e tratamento diferenciado em relação ao desporto não profissional.

32 Discurso na cerimônia de lançamento nacional da Loteria Timemania. Brasília, 4/5/2005.

${ }^{33}$ Lei no $10.671 / 2003$.

Movimento, Porto Alegre, v. 20, n. 2, p. 495-517, abr.jun. de 2014. 
o cadastro de membros das torcidas organizadas e criminalização da violência nos estádios.

Outros discursos associados a ações de governo no setor esportivo se destacam, como por exemplo, a referência ao futebol que Lula insistia em fazer mesmo quando sua agenda envolvia atividades de outros programas governamentais, ou mesmo em agenda envolvendo o esporte olímpico, normalmente, atividades ligadas aos Jogos. Entretanto, quando o assunto envolvia diretamente o futebol, os discursos de Lula se voltavam à sua principal meta, a modernização do futebol visando a organização e realização da Copa no Brasil.

Agora, aqui, no Brasil, nem o povo tem o poder aquisitivo suficiente e nem nós temos esse hábito, que precisamos adquirir, de fazer com que o clube vá se estruturando, porque nós estamos pleiteando a Copa do Mundo de 2014. Vocês sabem que, para a gente ter a Copa do Mundo de 2014 aqui - o Presidente da Fifa está vindo ao Brasil agora, no dia 28 de setembro -, pelos critérios da Fifa, nós não temos nenhum estádio em condições de sediar jogos da Copa. Significa que, se nós estamos pleiteando - e eu já fiz questão de tornar pública a vontade do governo brasileiro de ter a Copa do Mundo aqui, em 2014 - significa que nós vamos ter que pensar, no mínimo, em construir 12 novos estádios neste País. E não é responsabilidade dos clubes ou apenas da Confederação, é responsabilidade do governo federal, dos governos estaduais e dos prefeitos, é responsabilidade do nosso Banco de Desenvolvimento, é responsabilidade dos nossos bancos públicos, Caixa e Banco do Brasil, porque uma Copa do Mundo vai dar ao Brasil uma visibilidade que, possivelmente, a gente não tenha dimensão $0^{34}$.

Modernizar a estrutura político-administrativa do futebol visando a adoção de uma gestão empresarial, o que reflete o processo de profissionalização da modalidade, é uma tendência

${ }^{34}$ Discurso na cerimônia de sanção da Lei da Timemania. Brasília, 14/9/2006.

Movimento, Porto Alegre, v. 20, n. 2, p. 495-517, abr.jun. de 2014. 
que pode ser percebida a partir dos anos 1970, ganhando impulso com a Constituição Federal de 1988 e com o ordenamento liberalizante da Lei Zico e Lei Pelé35 (PRONI, 2000, FRANCO JÚNIOR, 2007, RODRIGUES, 2007). O que o governo Lula trouxe de novo, considerando a organização e realização da Copa, foi a intensificação de medidas de apoio à atividade sob a lógica do negócio, refletindo um novo momento do processo de modernização do futebol em nosso país, todavia, reforçando ainda mais o conservadorismo presente no relacionamento do Estado com as entidades de administração - clubes, federações e CBF e FIFA.

\section{ConsideraçõEs finaIS}

O lulismo é um fenômeno recente e seu sentido histórico não se fixou completamente. Cheio de ambiguidade e contradição, combinou mudança e conservação, superação e reprodução, esperança e decepção, tudo num mesmo movimento. Conforme pode se apreender de Singer (2012) e Ab'Sáber (2011), o governo de Lula e do PT não trouxe novidades e passou longe de qualquer reforma anticapitalista. Ao contrário, promoveu um pacto conservador e governou ao lado dos ricos e poderosos. Mas é verdade também que, do ponto de vista material e econômico, teve empenho redistributivo, o que, ao lado do simbolismo popular e poder carismático de Lula, garantiu a simpatia e adesão dos pobres e muito pobres.

Intentamos explorar a dimensão simbólica do lulismo, particularmente, suas mediações com o futebol. Sim, a presença do futebol no discurso de Lula foi marcante, algo que reflete sua formação cultural. Nunca nenhum presidente havia falado tanto de futebol, até porque, diferentemente dos antecessores, ele dominava seus códigos. Lula usou e abusou de sua linguagem para se comunicar, cultivando o sentimento do popular, do nacional e do moderno. Foi com estes sentidos que se pronunciou através do

\footnotetext{
${ }^{35}$ Respectivamente, Lei ${ }^{\circ}$ 8.672/1993 e Lei n 9.615/1998.
}

Movimento, Porto Alegre, v. 20, n. 2, p. 495-517, abr./jun. de 2014. 
futebol e sobre o futebol, seja por meio da metáfora, pela paixão corintiana, traduzindo um discurso torcedor e opinativo, ou do registro de suas ações envolvendo a modalidade. Em termos gramscinianos, Lula comandou um imenso avanço orgânico do consentimento, nos dizeres de Ab'Sáber (2011), do carisma pop e da cultura anticrítica, e o seu "futebolês" ajudou.

Lulismo y fútbol: los discursos de un hincha presidente Resumen: Este artículo analiza las mediaciones del lulismo con el fútbol, con el argumento de que el deporte está fuertemente asociada con el simbolismo popular y poder carismático de Lula. Así, se evalúa como se insertó el fútbol en los discursos del presidente. De la revisión y estudio de documentos, se analizaron 309 informes. Como resultado, se identificaron tres matrices discursivas: la metafóricos, en los que el lenguaje del fútbol es utilizado como una característica de identificación y proyección, la de Corinthians, na quali prevalece el discurso hincha y opiniones; pragmáticas, que acompaña a la agenda de modernización para la ejecución de la Copa Mundial de la FIFA 2014.

Palabras clave: Fútbol. Lulismo. Deporte. Política

\section{Lulism and football: the speeches of a rooter president}

Abstract: This article discusses the mediations of Lulism with football, sustaining that the modality has been strongly associated with popular symbolism and power charismatic of Lula. Thus, we seek analyze how football was inserted in the President's speeches. As from document review and survey, 309 reports were analyzed. As a result, we identified three matrices discursive: the metaphorical, in which the language of football is used as identificatory and projection; the "corintiana", which prevails discourse rooter and opinionated ; pragmatic, that accompanying schedule modernizing for the implementation of the 2014 FIFA World Cup.

Keywords: Football. Lulism. Sport. Policy.

\section{REFERÊNCIAS}

AB'SABER, T. Lulismo, carisma pop e cultura anticrítica. São Paulo: Hedra, 2011.

BARDIN, L. Análise de conteúdo. 4. ed. Lisboa: Edições 70, 2010.

Movimento, Porto Alegre, v. 20, n. 2, p. 495-517, abr.jun. de 2014. 
CAVALCANTI, E. A.; CAPRARO, A. M. Ronaldo X Lula: Uma análise do discurso na Folha de S. Paulo. Movimento, Porto Alegre, v. 18, n. 4, p. 121-134, out./dez. 2012.

DALTOÉ, A. S. A divulgação do discurso político: as metáforas de Lula e suas formas de interdição. Linguagem em (Dis)curso, Tubarão, v. 11, n. 3, p. 585-606, set./dez. 2011.

DAMATTA, R. (Org). Universo do futebol: esporte e sociedade brasileira. Rio de Janeiro: Pinakotheke, 1982.

DAMO, A. S. Futebol e estética. São Paulo em Perspectiva, São Paulo, v. 15, n. 3, p. 82-91, jul./set. 2001.

DAMO, A. S. Dom, amor e dinheiro no futebol de espetáculo. Revista Brasileira de Ciências Sociais, São Paulo, v. 23, n. 66, p. 139-150, fev. 2008.

FRANCO JÚNIOR, H. A dança dos deuses: futebol, cultura, sociedade. São Paulo: Companhia das Letras, 2007.

GONÇALVES, R. Novo desenvolvimentismo e liberalismo enraizado. Serviço Social e Sociedade, São Paulo, n. 112, p. 637-671, out./dez. 2012.

HELAL, R. Futebol e comunicação: a consolidação do campo acadêmico no Brasil. Comunicação, Mídia e Consumo, São Paulo, v. 8, n. 21, p. 11-37, mar. 2011.

MARX, K. O dezoito brumário de Luís Bonaparte. In: MARX, K; ENGELS, F. Obras escolhidas. São Paulo: Alfa-Omega, [19--]. v. 1. p. 199-285.

MASCARENHAS, F. et al. O bloco olímpico: Estado, organização esportiva e mercado na configuração da agenda Rio 2016. Revista da ALESDE, Curitiba, v. 2, n. 2. p. 15-32, ago./dez. 2012.

OLIVEIRA, F. Hegemonia às avessas. In: OLIVEIRA, F.; BRAGA, R.; RIZEK, C. (Org.). Hegemonia às avessas: economia, política e cultura na era da servidão financeira. São Paulo: Boitempo, 2010. p. 21-27.

PARANÁ, D. Lula, o filho do Brasil. 3. ed. São Paulo: Fundação Perseu Abramo, 2008.

PRONI, M. W. A metamorfose do futebol. Campinas: Unicamp/IE, 2000.

RODRIGUES, F. X. F. O fim do passe e modernização conservadora no futebol brasileiro (2001- 2006). 2007. 345f. Tese (Doutorado) - Curso de Sociologia, Instituto de Filosofia e Ciências Humanas, Universidade Federal do Rio Grande do Sul, Porto Alegre, 2007.

RUBIM, A. A. C. Cultura e política na eleição de 2002: as estratégias de Lula presidente. In: CONGRESSO DA COMPÓS, 12., 2003, Recife. Anais... Recife: Compós, 2003. p. 1-16.

SARDINHA, T. B. Lula e a metáfora da conquista. Linguagem em (Dis)curso, Tubarão, v. 8, n. 1, p. 93-120. jan./abr. 2008.

Movimento, Porto Alegre, v. 20, n. 2, p. 495-517, abr./jun. de 2014. 
SINGER, A. Raízes sociais e ideológicas do lulismo. Novos Estudos - CEBRAP, São Paulo, 85, p. 83-102, nov. 2009.

SINGER, A. A segunda alma do Partido dos Trabalhadores. Novos Estudos CEBRAP, São Paulo, 88, p. 89-111, dez. 2010.

SINGER, A. Os sentidos do lulismo: reforma gradual e pacto conservador. São Paulo: Companhia das Letras, 2012.

SOARES, A. J. G.; LOVISOLO, H. A invenção do país do futebol: mídia, raça e idolatria. Rio de Janeiro: Mauad, 2001.

Endereço para correspondência:

Faculdade de Educação Física - UnB

Campus Universitário Darcy Ribeiro

Asa Norte - Brasília-DF

CEP: 70910-970

Recebido em: 13.08.2013

Aprovado em: 16.02.2014

Movimento, Porto Alegre, v. 20, n. 2, p. 495-517, abr.jun. de 2014. 